vaccine, 50 to 70 million, was given, according to the index. Owing to the patient's nervous condition, and repugnance to the injections, treatment was stopped during the summer. Since beginning treatment the patient has gained $16 \mathrm{lb}$. weight, is stronger, and feels better than she has for some years. July 9. Colon index, 1.75 .

This case illustrates very clearly the fact that the recognized minimum dose of 50 million colon and 250 million staphylococcus vaccines may be harmful to some patients. Here the clinical and opsonic results were more beneficial following the doses of 3 to 5 million colon and 50 to 70 million staphylococci. In similar obscure cases the blood should be tested opsonically every other day, for at least three observations, to the various pathogenic organisms, viz.: T. B., staphylococci, streptococci, colon, pneumococci, and gonococci. Those which show persistently low indices are those to be subsequently treated by the proper vaccines, guided by the opsonic index.

BIBLIOGRAPHY.

1. Bullock: Proc. Roy. Soc., vol. $1 \mathrm{xxv}$.

2. Ibid. Med.-Chir. Soc. Proc., 1905 .

3. Ibid.: Practitioner, 1905, Nov., vol. $1 x x v$, p. 589

4. Ibid.: Trans. Path. Soc., London, i905, voi. lvi, pp. 334-344.

5. lbid.: The Lancet, 1905, vol. ii, p. 1603 .

6. Ibid.: London Hosp. Gaz., 1905, vol. xi, March.

7. Bullock and Atkin: Proc. Roy. Soc., 1905, voi. xxiv, p. 379. 8. Bullock and Ledingham: Lancet, Dec. 21,1905 , p. 1603. p. 531 .

10. Hektoen: Jour. Am. Med. Asso., May 12, 1906, p. 1407.

11. Ibid.: Jour. Infect. Dis., vol. iii, no. 1, March, 1906, pp. 102-109. 12. Ibid.: Trans. Chicago Path. Soc., vol. vi, 1906, no. 11, $p_{13}$ 408-409.

13. Ibid.: Jour. Infect. Dis., vol. iii, no. 3, May, 1906, pp. 434-440. 14. Ibid.: Jour. Infect. Dis,, vol. $i$, 1906, p. 102

15. Hektoen and Reudiger: Jour. Infect. Dis., 1905, vol. ii, pp. 128-141.

16. Hollister: Surg., Gyn. and Obstet., Chicago, vol. iii, no. 6, p. 740 .

17. Houghton: Therap. Gaz., Detroit, Jan., 1907.

18. Lawson and Stewart: Roy. Med. and Surg. Soc., London, Nov. 14,1905 .

19. Ibid.: Lancet, 1905, vol. ii, pp. 1679-1684.

20. Leary and Medalia: Med. Com. of Mass. Med. Soc., vol. xx, no. 111,1907, p. 671 .

21. Löhlein: Ann. de l'Inst. Pasteur, 1905, vol. xix, p. 647.

22. Ibid.: vol. xx, 1906, pp. 939-961.

23. Ibid.: Centralbl. für Bakteriol., Abt. T, Ref., vol. xxxviii, 1906, pp. $32-36$.

24. Macdonald: Trans. Path. Soc., London, vol. Ivii, 1906, p. 45. 25. Ohlmacher: Jour. Am. Med. Ässo., Feb. 16, 1907, p. 571 .

26. Potter, Ditman and Bradley: Jour. Am. Med. Asso., Nov. 24, Dec. 1,1906 .

27. Ibid.: Am. Jour. Med. Sc., Aug., 1906, pp. 186-202.

28. Ross: Canadian Lancet, Jan., 1907.

29. Ibid.: Brit. Med. Jour., London, July 6, 1906

30. Ibid.: London, Nov, 24,1906 , p. 1452 .

31. Reudiger: Jour. Am. Med. Asso., 1906, vol. xlvi, p. 108.

32. Ibid.: 1905, vol. xliv, p. 198 .

33. Ibid.: Trans. of sec. on Path. and Phys. of Am. Med. Asso. $1904, \mathrm{p}, 397$.

34. Ibid.: Jour. Infect. Dis., vol. iii, 1906, pp. 102-109.

35. Simon: Johns Hopkins Hosp. Rep., Jan., 1906.

36. Ibid.: Jour. Am. Med. Asso., Jan. 12, 1907, p. 139.

37. Simon, Lamar, Bispham: Jour. Exper. Med., Dec., 1906.

38. Wright: Notes on the treatment of furunculosis, sycosis and acne by the inoculation of a staphylococcus vaccine; and generally on the treatment of localized bacterial invasions by therapeutic inoculations of the corresp

39. Ibid.: On the measurement of bactericidal power of small samples of blood under aërobic and anaërobic conditions, and on the comparative bactericidal effect of human blood drawn off and tested under these contrasted conditions. Proc. Roy. Soc., vol $\mathrm{xxi}, 1902$.

40. Ibid.: On some new procedures for the examination of the blood and of bacterial cultures. Under this, (2) On a method of determining under the microscope the number of micro-organi
contained in a bacterial culture. Lancet, July 5,1902 , p. 11 .

contained in a bacterial culture. Lancet,

42. Ibid.: Brit. Med. Jour., i i 902 , vol, i, p. 866

43. Ibid.: A lecture on therapeutic inoculation of bacterial vac-

cine. Brit. Med. Jour., May 2,1903 , vol, i, pp. 1069-1074.

45. Ibid.: A note on the serum reaction of tubercle. Lancet

May 9, 1903, p. 1299 .

46. Ibid.: Brit. Med. Jour., 1903, vol. ii, p. 906.

47. Ibid.: Lancet, 1903 , vol. ii, p. 214 .

48. Ibid.: Lancet, 1903, vol. ii, p 1008 .

49. Ibid:: A short treatise on anti-typhoid inoculation. An exposition of the principles of the method and a summary of the practitioner, Jan.-March, 1904 .

50. Ibid.: Lancet, 1904, vol. ii, p. 411.

51. Ibid:: On the treatment of acne, furunculosis and sycosis by the therapeutic inoculations of staphylococcus vaccine. Brit. Med.
Jour., May 7, 1904, p. 1075 .
52. Ibid.: Brit. Med. Jour., 1904, vol. ii, p. 582.

53. Ibid.: 1904, vol. ii, p. 1342 .

54. Ibid.: p. 1489.

56. Ibid:: A lecture on the inoculation treatment of tuberculosis Clin. Jour., 1904.

57. Ibid.: Pathological suggestions. (1) The preparation of microscopic slides for blood films. Lancet, July 9, 1904

58. Ibid.: On the general principle of the therapeutic inoculation of bacterial vaccines as applied to the treatment of tubercular infection. Lancet, 1905, vol. li, pp. 1598-1675.

59. Ibid.: Zeitschr. für Hyg., Sept., 1903 , vol. lxxii, p. 130.

60. Ibid.: The opsonic theory. Canadian Practitioner and Review vol. xxi, 1906 , p. 605 .

61. Ibid.: Lancet, 1906, vol. i, p. 237.

62. Ibid.: p. 1609 .

63. Ibid.: Brit. Med. Jour., 1906, vol. i, p. 143.

64. Wright and Douglas: An experimental investigation of the role of the blood fluids in connection with phagocytosis. Proc. Roy. Soc., vol. lxxii, 1903 , pp. $357-370$.

65. Ibid.: On the action exerted upon the tubercle bacillus by human blood fluids, and on the elaboration of protective elements in the human organism in response to inoculation of a tubercle vaccine. Lancet, 1904 , vol. ii, p. 1138 .

66. Ibid.: Further observation on the role of the blood fluids in connection with phagocytosis. Proc. Roy. Soc., vol. Ixxiii, 1904, pp. 128-141.

67. Ibid.: On the action exerted upon the staphylococcus pyogenes by human blood fluids and on the elaboration of protective elements in the human organism in response to inoculations of a staphylococcus vaccine. Proc. Roy. Soc., vol. lxxiv, 1905, pp. $147-159$.

68. Ibid.: Proc. Roy. Soc., 1904, vol. lxxiv, p. 160.

69. Wright and Reid: On spontaneous phagocytosis, and on the phagocytosis which is obtained with the heated serum of patients who have responded to tubercular infection, or, as the case may be,
to the inoculation of a tubercle vaccine. Proc. Roy. Soc., 1906, vol. lxxvii, pp. 211-225.

70. Ibid.: On the possibility of determining the presence or absence of tubercular infection by the examination of a patient's blood and tissue fluids. Proc. Roy. Soc., 1906, vol. Ixxvii, pp. 194-211.

71. Wright and Windsor: Jour. of Hyg., Oct., 1902, vol. ii, no. 4.

\section{THE “OPTOMETRIST," DOES HE PREACH AND PRACTICE MEDICINE?}

BY JOHN C. BOSSIDY, M.D., BOsTON,

Ophthalmic Surgeon, Boston City Hospital.

MY article on "The Optometrist," of the 26th ult., has resulted in many queer optical advertisements reaching me by mail, of which the following is easily the masterpiece:

TO THE PUBLIC.

You should use the same care in selecting your optician that you do in selecting your physician. It has been recently discovered that eyestrain is responsible for many of the ills of humanity, such as headache, stomach trouble, piles, constipation, female troubles, epileptic fits, St. Vitus' dance and many other so-called incurable diseases.

The Littlefield system of eye and nerve measurements, of which I am a graduate, has revealed to the world the true cause of these functional nervous diseases, and I extend to you a cordial invitation to call in and have your eyes tested by this new copyright method. I make a specialty of straightening cross eyes in children without an operation, which would be painful and dangerous. Every schoolboy and girl in this country should have their eyes tested by this new system at once to see if there is any latent eyestrain undermining their health.

I furnish glasses of all kinds and descriptions at lowest prices.

Respectfully,

Optometist.

We take it that this man would seek registry under the proposed Optometry Bill.

In Optical Journal, Feb. 8, 1906, we note a communication from the then president of the New England Optical Association in reference to the founding of an "optometrical academy":

"I first met and conversed with this gentleman on the top floor of a large department store of this city, where he then had charge of eye fitting and glass selling for the firm." 
The November, 1907, Keystone, an optical or jeweler's journal, gives the subjects of monthly lectures before the New England Association of Opticians as follows:

"December, 1907: 'Muscular Anomalies'; esophoria, exophoria, hyperphoria, spasm of accommodation. January, 1908: 'Strabismus '; convergent, divergent, alternating, concomitant. February, 1908: 'Methods'; subjective, objective, fogging, retinoscopy, ophthalmoscopy. March, 1908: 'Amblyopia'; alcoholic, tobacco, diabetic, uremic, hysteric, albuminuric, simulated. .April, 1908: 'Adjustment of Glasses.' "'

All of these subjects, save the last, seem medical rather than optical. In Optical Journal, 1904, page 44, President Grainger, of Northwestern Optical Association, says,

"The optometrist is the one to apply to for relief from headache, eyestrain, etc."

An editorial in the same journal, of the same year, page 71 , says that a course in the diagnosis of ocular disease is unattainable, as it can only be found in medical and post-graduate schools, and in these the entrance conditions are rigid. It adds that optometrists must get practical work of this kind by private study and the observation of their own cases. In the July 28, 1904, Optical Journal we find a stated talk before the Northwestern Optical Association, in which the speaker says:

"The optometrist, to meet with the greatest measure of success and to be successful in the greatest number of cases, must use every means in his power to completely, perfectly and positively diagnose not only the errors of refraction, but every abnormal condition of the eye under examination."

"Neuritis, retinitis and albuminuric retinitis are not usually difficult to diagnose."

Before the Canadian Optical Association, in 1904, an ex-president of the National (American) Association of Opticians spoke as follows:

\footnotetext{
"The analytical and progressive optometrist is constantly confronted by conditions which emphasize the intimate relationship existing between the various human functions, and the truth that an abnormal condition of one may produce sympathetic reflex disturbances in the other; and he should, therefore, have that comprehensive knowledge of the physiology of the ocular functions, their nerve and blood supply, as well as of those collateral interrelated, and therefore likely to be affected by ocular disturbances or imbalances, so as to be able to recognize symptoms indicating these, and trace such reflexes to their cause."
}

In the Optical Journal of Feb. 23, 1905, we find a communication in which the writer says that he signs a contract to cure ptosis of twenty years' standing. He has a dozen cases on hand, every one guaranteed to be perfectly straight; three cases of spasms, one of bed wetting, many of indigestion of even twenty years' standing, dyspepsia, female troubles, etc.

Before the Nebraska State Optical Society, the Journal of Feb. 22, 1906, cites a speaker as saying that he knows of no one who condemns extra ocular muscle development if he understands the subject thoroughly and has given it a fair and impartial trial. He says:
" It relieves suffering humanity when all else fails, and affords a good legitimate income for the Optometrist."

Returning to 1904, we find the January and February lectures before the New England Optical Association at its monthly meeting to be, "Fundus Oculi: Its Pathological Variations." The March lecture delivered by a layman was, "Ocular Muscles and Clinical Use of Prisms." In 1906 the present secretary of the Massachusetts Optical Society is quoted in an Optical Journal as follows:

"I think the best plan would be a course in a college, taking up anatomy, physiology, histology and natural philosophy, and then to learn higher mathematics. Perhaps a correspondence course, if it were thorough, might educate the opticians of the country," etc.

This man's business sign reads on the office directory, "Optician \& Watchmaker."

In the circular letter recently mailed by the Massachusetts Optical Society to the physicians of this state, we find the statement that,

"The fitting of glasses to the eyes is a mechanical process dealing with the refracting of the rays of light before they enter the eye."

The same remark is made officially by the president of the National Optical Association when he says:

"That as the optician refracts or bends rays of light with his lenses before they enter the eye and not afterwards, he is treating light, not treating disease."

We therefore assume that he is correct; that the process is purely mechanical, and that he and his colleagues wish to make mechanical work a profession.

Let us, then, see from their own claims, both written and spoken, whether or not this be true, or whether they do really pretend to treat the eye internally and to diagnose disease, which action would constitute to our mind the practice of medicine.

Going back beyond the birth of so-called optometry we resurrect a letter, dated Dec. 19, 1899, written by the mentor and predecessor in business of our before-mentioned national president.

In this letter to the Optical Journal, of New York, he advocates the establishment of a New York optical school and advises them to seek the advice of a conscientious oculist who will lay out a plan and course of study that will insure high standing for the school.

He tells them to place their standard high, and notes that the trustees of the New England Optical Institute recognize that unless the optician is to take a secondary place in optical matters he must have a liberal education. (The New England Optical Institute has long since died.) He gives a synopsis of the sixty lectures to be delivered to his second year students as follows:

"The individual protoplasmic cells; the amoeba and ovum; general histology; physiology of the blood; physiology of digestion; chemistry of the animal body; general structure of the body; osteology in general; special study of cranial bones; physiology and anatomy of muscular 
system; physiology and anatomy of brain and spinal cord; practical talks on viscera of body; practical demonstration on skeleton, manikin and viscera; the anatomy and physiology of the eye by fifteen or more lectures and five quizzes."

This class is also studying trigonometry and later will take up chemistry. Last year physics, algebra and geometry were studied. Next year will be devoted to pathology, refraction and accommodation. He adds that "the oculist is too much of a physician, and the optician not enough of a physiologist."

(I mention this man in particular because he has been quoted as being among the prime movers of the establishing of an optical association. $\mathrm{He}$ was then also connected with a wholesale optical house of this city; as was a colleague whose name was mentioned in the same connection. See the Optical Journal, January, 1902, page 46.)

The prospectus of the New England Optical Institute for 1899-1900 says:

"The student in optometry is taught to recognize diseased conditions of the eye, and also such abnormal conditions of the system as effect the eye."

"He is educated to correct all forms of ametropia and disturbances of the ocular muscles; to understand all methods of measuring refraction, accommodation and muscular disorders, and the use of all optical instruments for optometry.

"The graduate of this school will be capable of understanding the most scientific and valuable works upon all subjects which have a bearing upon the prescribing of glasses, and he should be able to judge for himself and take his stand as an authority on the care of the eye."

Does he preach the practice of medicine?

I find their third year studies published as " Pathology (including neurology), ophthalmology, optometry (refraction, accommodation, retinoscopy, etc.), mechanical work and clinical training."

Were they studying medicine? Did they diagnose disease? Did they preach medicine?

In the Optical Journal of April 15, 1899, we find an article on the ocular muscles as read before the New England Association of Opticians by the lay president of the New England Optical Institute.

He there goes into the deep anatomy of the ocular muscles; into the intimate anatomy of the brain; discourses learnedly on nervous energy, the degeneration of the nerve itself, the degeneration of the arteries, obstruction of blood vessels and troubles which may cause paralysis. He notes how occasionally intoxication, tuberculosis, diabetes, inflammation of the kidneys, diphtheria, influenza or rheumatism may bring on a paralysis of the ocular muscles.

He notes that specific trouble is the underlying cause of nearly $60 \%$ of ocular paralysis and wishes the optician to remember that fact. $\mathrm{He}$ says that it will be the optician's privilege to correct headaches that have been attributed to neuralgia or other causes, and that have been in physicians' care for a long period of time. He advises them to test carefully the cases of violent headaches, dizziness, nervousness and unconscious spells. He advises them to question the health and to expect in the aged muscular errors arising from intracranial weakness.

He sums up a deeply scientific article by advis- ing them to measure the refraction in the dark room; to test each eye separately by the subjective method; to test the muscular balance; to measure adduction, abduction, superduction and infraduction; to test for concomitancy; to test the muscle balance at the near point and the power of convergence in accommodation; to consider the symptoms and the state of health, and after having tested the abnormal conditions a number of times, tells them that they are ready to form an opinion and to prescribe intelligently for the refractive or muscle error.

His concluding words refer to the use of prisms. He advises them that after feeling sure that the symptoms complained of do not come from ill health or the need of astigmatic or spherical glasses or from peculiar habits of work, they may try their skill at prisms, entertaining the hope that much good and no harm will be done.

Did he then preach the practice of medicine?

Their 1900-1901 announcement gives a faculty of six (three professors and three instructors), covering the subjects, ophthalmology, anatomy, histology, embryology, pathology, chemistry, physics, physiology, hygiene, optometry and mathematics.

Their list of students numbers sixteen. This was the year in which this school sought legislative authority to grant degrees of "Doctor of Optics " and "Bachelor of Physiological Optics," in reference to which matter I quote from a Boston newspaper of that year:

"The petition has this peculiar feature, that the students themselves of the school are at the same time likely to be both their own judge and jury. This appears in the fact that out of 16 students now attending the school, 9 are named as incorporators; 8 are advertised as trustees, and 4 out of 5 officers of the Board of Trustees are also of these sixteen students. The query arises whether they would refuse to graduate a student who happens to be an incorporator. Would not the faculty take pride in graduating a student who also happens to be a trustee? Would not the faculty literally fall over itself in feverish desire to grant the aforesaid degree of $D$. $O$. to a student who had already reached the eminence of officer of this Board of Trustees? Even Poo Bah might well give place to these educators."

I have been thus discursive in reference to this school because it shows how profuse they were in promises, how largely they entered into the study of medicine, how small a place optics took in their curriculum, and how soon the school died when they were refused the privilege of granting degrees.

I would not quote this man, now that be is dead, were it not for the fact that the optical company, of which the president of the National Optical Association is now the leading spirit, has sent leaflet after leaflet to the physicians of this state extolling his teacher's life labors as the originator or discoverer of a perfect, or almost perfect, system of eye measurements, adding request or invitation that physicians refer cases to them for diagnosis or examination.

This jump from 1899 to the present day indicates to my mind that his firm then practiced, as it now practices, medicine in as far as they 
pretend to correctly fit glasses and to absolutely diagnose disease. In the January number of the Optical Journal of 1901 , page 46, we find an address delivered before the New England Association of Opticians in which the speaker dilates upon their need of an understanding of physiological optics, adding that the optician should know enough about disease to " know a case of locomotor ataxia from inebracy" (inebriety?), and how certain diseases may affect the index of refraction of the dioptric media. Does that mean that they should know medicine?

In 1904 we reach the tenth annual meeting of the New England Association of Opticians, held at Boston, May 17, and find a speaker addressing them on the subject, "Objective and Subjective Optometry with Retinoscope, Ophthalmoscope and Trial Case ":

"Every refractionist should use the retinoscope, ophthalmoscope and trial case, all of them; with the ophthalmoscope he must learn to differentiate a physiological from a pathological fundus; that because of the great number of cases passing through the refractionist's hands, he can refract better and faster than an oculist can, and this being so, why should he not examine the patient's fundus to see whether a diseased condition is present or not?"

In this connection the speaker enthusiastically recommended, because of the plates, Haab's Atlas.

"Look into the eye as a matter of routine," he said, " and soon the oculist's sphere will become restricted to what it should be: surgery, surgical and medical treatment of diseased eyes."

Did he talk and did they listen to a medical discourse? Did he seek to restrict the medical man's field of work? The program of the American Association of Opticians for their annual meeting at Rochester, N. Y., in 1906, contains these subjects as stated addresses: "Monocular Amblyopia Due to Congenital Corneal Asymmetry "; " The Eye in Comparative Anatomy"; "Some Diseases Essential for the Optometrist to Recognize"; "Mechanism of Accommodation "; "Illumination of the Eye by Direct and Oblique Methods," and "The Eye in Relation to Health." During this last lecture it is stated that a free clinic will be held demonstrating the effect of lenses in cases of stammering, partial deafness, St. Vitus' dance and shaking palsy.

Did not their convention take on a medical tone?

That medicine and medical matters are always dominant in these optical meetings is indicated by an address last year before our same New England Association of Opticians. The speaker says:

"If we have a school and that school is good for anything, it must stand for something; it must stand all criticism. The school that gives us no title, that gives us not standing, we do not want. We want a school that will give us a degree, but one that will not encroach upon the field of medical profession. We want a school that will make a specialty of teaching refraction. Some six or seven years ago we had a school here, but there has been no attempt made to have such a school exclusively for the opticians."

As a matter of fact, my quoted words on a former page would seem to indicate that they aimed to teach medicine rather than refraction. This speaker adds that -
"The optician ought to know every disease, that shows ocular symptoms; be familiar with the signs of disease, to know the limits of his work and to know them well.

"The school should go into the anatomy of the eye and of the associated parts particularly; should teach physiology as it relates to the eye and its parts.

The school should have sessions in the evening, so that every one may go, and the course should be one of two or three years."

Once again: Do these gentlemen tread on the domain of medicine? We quote remarks made before our New England Association of Opticians. (See Optical Journal, May 31, 1906.)

The speaker first takes the ophthalmoscope and examines the fundus; next the cornea, crystalline and iris.

"This takes but a short time," he says, "for an expert with the ophthalmoscope, and there is no reason why every man could not be an expert by devoting a few hours a day to practice. He will then be soon able to know almost at a glance whether or not disease exists."

He next examines the refractive media, then goes to the subjective test, after which he gauges the accommodation by the method of Donders; then he proceeds to test the muscles, using Maddox prism, candle or globe.

Though he says much more on the subject, these words suffice to give us an idea of whether or not he examines the eye internally or diagnoses disease.

I take up now some of the national president's literature, and after a hasty glance at the same, note that they say:

"The family physician meets with many cases where the reflex symptoms indicate eyestrain, and that the physician in such circumstances would find satisfaction in sending cases where the work would be done correctly and where the people will have the ability to fulfill such requirements." I. e., absolute correctness is claimed by this same firm.

They claim, without the use of drugs, to be able to scientifically, practically and accurately prescribe just the correction which a patient should have.

They make an especial announcement that they examine the cornea and retina with the ophthalmoscope and oblique illumination to see whether or not abnormal conditions exist.

They request the privilege of working with the physicians for the relief of cases where the reflex symptoms indicate eyestrain.

Do these gentlemen pose here not only as medical men, but as medical experts or consulters?

Once again the writer asks, Do they preach or practice medicine? Let the reader answer.

Your writer has not quoted their most radical statements. He has selected mild extracts, though he could fill page after page in noting how they could use in some cases the title " Doctor" without let or hindrance; how superior they are in eye knowledge to the medical man, etc. The physician, the dentist, the pharmacist, have their schools and their stated subjects of study; these men have no schools.

For years the House of Delegates, Board of 
Regents or Physiological Section of the National Optical Association have discussed the ways and means of establishing an optical college or optometrical academy, and all to no avail. Not a mouse has answered the mountain's labor, and the school is still in the womb of futurity.

\section{Iteport of Docieties.}

\section{THE MEDICAL ASSOCIATION OF THE GREATER CITY OF NEW YORK.}

Stated Meeting Held at the New York Academy of Medicine, OC'T. 21, 1907.

'The President, Dr. Thomas E. Satterthwaite, in the chair.

The general subject of the evening was

The Stomach and Some of Its Affections.

It was introduced by Dr. William H. Porter, who spoke on

THE ORIGIN AND DESTINATION OF HYDROCHLORIC ACID.

Certain fundamental facts, he said, must be taken into consideration in making out a logical theory for the formation of hydrochloric acid, namely: (1) The proteid molecule leaves the body by a process of oxidation reduction. (2) The cells of the gastric mucous membrane can produce sulphuric acid. (3) The decomposition of the sodium chloride of the food is generally admitted to be the source of the hydrochloric acid. (4) The intake and output of sodium chloride is always equal. (5) The output of sodium sulphate is always greater than the intake. (6) The food contains an abundance of alkaline sodium phosphate and very little neutral sodium phosphate. (7) The blood contains a considerable amount of the neutral phosphate. (8) The urine is rendered acid by the acid sodium phosphate. From these facts the speaker argued that the proteid molecule is drawn with oxygen into the protoplasm of the gastric epithelial cells, and there, by a process of oxidation reduction, sulphur and hydrogen are split off, with the formation of sulphuric acid, which is discharged into the stomach from the free surface of the cells. The sulphuric acid here attacks the sodium chloride forming hydrochloric acid and sodium sulphate After the hydrochloric acid has served its purpose in the digestive act, it reacts upon the sodium phosphate in the intestinal tract, restoring the sodium chloride lost in the stomach, and produces the neutral phosphate for the blood. The neutral phosphate, escaping from the blood through the malpighian tufts, comes in contact in the uriniferous tubules with the uric acid, thus forming the acid phosphate and a urate. Considered in this light, the complete utilization of $150 \mathrm{gm}$. of proteid material daily, after deducting the amount of sulphur required to form the taurocholic acid, leaves sufficient sulphur to produce $5.78 \mathrm{gm}$. of sulphuric acid. This amount of sulphuric acid, acting upon the requisite amount of sodium chloride, will yield $4.29 \mathrm{gm}$. of hydrochloric acid and $8.37 \mathrm{gm}$. of sodium sulphate. The utilization of a smaller or larger amount of proteid material will naturally decrease or increase the production of the acids. The practical deduction to be drawn from this method of accounting for the formation of the acids is that, where there is an increased production of hydrochloric acid, there is a decreased pro- duction of taurocholic acid; or, estimating the production for a short time, as is commonly done, this might indicate temporary increased oxidation reduction for a short period. Until some method is devised by which the total daily output of the acids can be practically estimated, all deductions must be largely speculative. Decreased production of the acids naturally indicates the reverse of the above conditions.

DR. J. KaUfmanN read a paper on

LACK OF GASTRIC MUCUS AND ITS RELATION TO HYPERACIDITY AND GASTRIC ULCER.

in which he said he wished to report some observations showing that the secretion of gastric mucus is a necessary function, and that lack of mucus leads to serious disturbances. While it was true that mucus was constantly secreted in the stomach to some extent, it appeared that such secretion was principally connected with the digestive period. From systematic tests he early became convinced that stomach contents under normal conditions show a moderate amount of mucus after meals and that lack of mucus must be considered abnormal. His results were obtained from the routine examination, in the same way, of several thousand cases. The presence of mucus was recognized by its most characteristic quality, its coherency. When no mucus was present, the coherency of the bread mass after a test breakfast was missed, and the lack of mucus was most obvious where the bread was found to be very finely divided and forming a flour-like layer. The presence or absence of mucus should, however, be corroborated by the microscopical findings, which were very characteristic. In these, staining the specimen with Lugol's solution was of great practical service, and from the combined results of macroscopic and microscopic examinations the amount of gastric mucus present in any instance could be readily estimated. Thus it was found that, under normal conditions, a moderate amount of mucus was found in the breakfast, while in pathological conditions the mucus was either increased, decreased or absent.

The amount of mucus did not correspond with the amount of gastric juice. In certain cases of achylia gastrica, increased qualities of mucus were seen, and in others, no mucus at all. On the other hand, although cases of hyperacidity, as a rule, showed a lack of mucus, instances were sometimes observed in which there was increased mucus. In his observations after a test breakfast, Dr. Kaufmann had noted a lack of mucus in a great number of cases. This was more frequent than an increase, and might be due to different causes. There was either insufficient secretion, or the secreted mucus was digested, or it was dissolved by the action of bacteria, as was seen in certain cases of bronchoblenorrhea. A certain amount of mucus was possibly digested by an active gastric juice; but several considerations militated against the probability that a complete lack of mucus in the breakfast was entirely due to its being digested. No matter what the cause of the lack of mucus, he thought we were justified in concluding that the lining of the stomach is not well covered with mucus when we find none in the gastric contents after a test breakfast. It was therefore obvious that the mucus is the protective agent of the gastric mucosa. In instances where no gastric juice or gastric juice of low acidity was secreted, it might be of no great importance, whether the mucosa was covered with a thick or thin layer of mucus; but the case was altogether different where there was an active gastric juice, and especially one of high acidity, because it was the layer of mucus which protected the mucosa against the action of the acid secretion.

An analysis of many histories had convinced him 